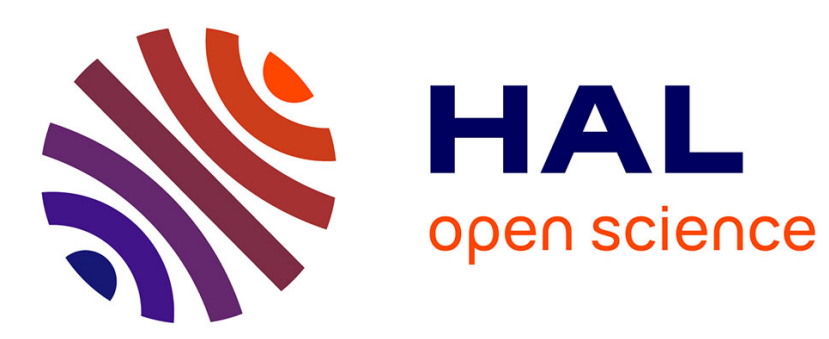

\title{
What is needed to overcome egoism?
}

Carsten Schradin

\section{- To cite this version:}

Carsten Schradin. What is needed to overcome egoism?. Trends in Ecology \& Evolution, 2021, 10.1016/j.tree.2021.10.015 . hal-03460390

\section{HAL Id: hal-03460390 \\ https://hal.science/hal-03460390}

Submitted on 1 Dec 2021

HAL is a multi-disciplinary open access archive for the deposit and dissemination of scientific research documents, whether they are published or not. The documents may come from teaching and research institutions in France or abroad, or from public or private research centers.
L'archive ouverte pluridisciplinaire HAL, est destinée au dépôt et à la diffusion de documents scientifiques de niveau recherche, publiés ou non, émanant des établissements d'enseignement et de recherche français ou étrangers, des laboratoires publics ou privés. 


\section{What is needed to overcome egoism?}

2

3 Carsten Schradin ${ }^{1,2, *}$

4

$5 \quad{ }^{1}$ CNRS, UMR7178, 67087 Strasbourg, France

$6{ }^{2}$ School of Animal, Plant and Environmental Sciences, University of the Witwatersrand, South 7 Africa.

8

9

10

11

12

13

14

15

16

17

\section{Published as}

Schradin, C. 2022. What is needed to overcome egoism? Trends in Ecology \& Evolution. 37: xxx 10.1016/j.tree.2021.10.015
For decades, behavioral ecology has fought the misunderstanding that explanations are justifications [1]. Behavioral ecology can explain aggression and violence between the sexes, why animals cheat in social interactions, show infanticide, kill adult con-specifics, and how this can increase individual fitness [2]. The same approach has been used to explain such behaviors in humans, which can help us to understand why and when these behaviors are shown, possibly helping us to prevent them [3]. As such, I fully agree with the statement of Menzel et al. [4] that evolved egoistic behavior is no excuse for insufficient actions to reduce climate change. I agree with Menzel et al that humans are not generally too egoistic for climate change mitigation (CCM). In fact, we do see climate change mitigation (CCM) at all levels, from individuals to communities to countries. But at the same time greenhouse gas emissions have been continuously increasing, climate change has been happening and will continue.

Adequate carbon pricing would be a good way to reduce $\mathrm{CO}_{2}$ emission. Currently (November 2021), energy costs are increasing drastically, and there is pressure from the public (the voters) 
to do something about it. The response of many countries (i.e. from their ruling politicians) has been to subsidize these costs, such that everybody can afford to burn fossil fuels. This supports my argument that cooperation in humans (public pressure on politicians) typically leads to individual benefits via resource acquisition, which is typically associated with increased $\mathrm{CO} 2$ emissions (see Box 2 in [5]). In agreement with this, Menzel al cite one paper showing that humans prefer to cooperate to achieve the greatest benefit for group-members over cooperation to allocate resources to environmental conservation [6].

Menzel et al. correctly argue that reducing climate change would be positive for many people living now and their children. However, it is a fallacy to believe that this would make CCM adaptive: If a population of people accepts certain costs (for example carbon pricing) to make $\mathrm{CCM}$ sufficient to reduce global warming to $1.5^{\circ} \mathrm{C}$, egoistic individuals that benefit from these actions without contributing to them would have an advantage. This is the well known tragedy of the commons (see box 1 in [5]).

People in the western world see that CCM is of high importance [7] and they do feel good when they show such behaviors [8]. However, it is important to note that showing behavior in accordance with CCM is not sufficient to stop climate change. For example, rich people in rich countries might invest into CCM by installing solar panels and buying electric cars. While they are rich enough to afford this without reducing their current standard of living, their individual $\mathrm{CO}_{2}$ footprint is still several times higher than what would be needed on average to restrict global warming to $1.5^{\circ} \mathrm{C}$. Such behavior will improve their own prestige, an evolved mechanism to increase fitness [9], but this is no indication that humans are cooperative enough to restrict global warming.

I agree with Menzel et al that adaptation to a changing climate will not be sufficient. This is why I proposed in my last paragraph that "we fight for a reduction in $\mathrm{CO}_{2}$ emissions" [5]. Nevertheless, empirical evidence of how we behaved since The First World Climate Conference in 1979 cannot be ignored: even though scientists have told us that we must reduce 


\section{References}

greenhouse gas emissions for decades, we continuously increased them! I do not think that societies and politicians failed the last decades because behavioural ecologist argued that human behaviour is egoistic. The fact that we could have done better in the past cannot be used as an argument why we should not invest in technology that helps us to reduce greenhouse gas emissions in the future. For all three actions, i.e. immediate reduction, investment in technologies, and adaptation of our societies to a changing world [5], we need clear communication between scientists as well as between scientists and society.

Explaining the adaptive value of behavior that is detrimental for the society does not justify this behavior, but understanding the evolutionary mechanisms behind it could help to come to better mitigation strategies [3]. The Letter by Menzel at al. [4] provides little scientific insight into why we have failed and how we could change this. How have human societies fought egoistic behavior that is detrimental for the society in the past? Legislation and politics are the main mechanisms in human societies to cope with egoistic individual behaviour. While for Menzel at al. [4] my article "left the impression that evolutionary-adapted egoism could be used as an excuse for insufficient CCM", I want it to be used as an argument to convince people to vote for a change in politics and legislation, as this is the main mechanism human societies have to fight against individual egoism.

1. Dawkins, R. (2017) Science in the Soul: Selected Writings of a Passionate Rationalist, Penguin Random House. 2. Wilson, E.O. (1975) Sociobiology: The new Synthesis, Harvard University Press. 3. Workman, L. and Reader, W. (2021) Evolutionary Psychology: An Introduction, Fourth edn., Cambridge University Press. 4. Menzel, C. et al. (2022) Response to Schradin (2021): Egoism alone does not explain climate inaction. Trends in Ecology and Evolution. 
81 5. Schradin, C. (2021) Corona, climate change, and evolved human behavior. Trends in Ecology 82 \& Evolution 36 (7), 569-572.

83 6. Klein, S. et al. (2017) Which is the greater good? A social dilemma paradigm disentangling 84 environmentalism and cooperation. Journal of Environmental Psychology 53.

85 7. Leiserowitz, A. et al. (2020) Climate Change in the American Mind. Yale Program on 86 Climate Change Communication

87 8. Zawadzki, S.J. et al. (2020) Meta-analytic evidence for a robust and positive association 88 between individuals' pro-environmental behaviors and their subjective wellbeing. 89 Environmental Research Letters 15, 123007.

90 9. Wright, J. (2007) Cooperation theory meets cooperative breeding: exposing some ugly truths 91 about social prestige, reciprocity and group augmentation. Behavioural Processes 76, 142- 148. 